\title{
Ekmeklik Buğdaylara (Triticum aestivum L.) İki Aşamalı Uygulanan Tavlama İşleminin Unun Ekmeklik Özelliklerine Etkisi
}

\author{
Mustafa Kurt ${ }^{1}$, Halef Dizlek ${ }^{2 *}$ \\ ${ }^{1}$ KOSGEB Osmaniye İl Müdürlüğü, Osmaniye, Türkiye (ORCID: 0000-0001-5849-6043) \\ 2 Osmaniye Korkut Ata Üniversitesi, Mühendislik Fakültesi, Gıda Mühendisliği Bölümü, Osmaniye, Türkiye (ORCID: 0000-0001-5873-5462)
}

(İlk Geliş Tarihi 12 Şubat 2020 ve Kabul Tarihi 5 Mart 2020)

(DOI: 10.31590/ejosat. 688149)

ATIF/REFERENCE: Kurt, M., \& Dizlek, H. (2020). Ekmeklik Buğdaylara (Triticum aestivum L.) İki Aşamalı Uygulanan Tavlama İşleminin Unun Ekmeklik Özelliklerine Etkisi. Avrupa Bilim ve Teknoloji Dergisi, (18), 445-453.

$\ddot{O} \mathbf{z}$

Bu çalışmada; buğdaya iki aşamada uygulanan tavlama işleminin buğdayın ekmeklik kalitesi üzerindeki etkileri araştırılmıştır. Çalışmada, çeşit özellikleri farklı 2 buğday örneği (Adana-99 ve Rus) kullanılmıştır. Her bir buğday çeşidinde tavlama ile ilgili 4 ayrı muameleye yer verilmiştir. Bunlar; a. tavsız (=kontrol), b. 24 saat süreyle bir kez tavlı, c. 48 saat süreyle bir kez tavlı ve d. 48 saat süreyle iki kez tavlı. Söz konusu muameleler neticesinde değirmene beslenen buğday örneklerinden elde olunan un numuneleriyle standart bir metotla ekmek üretilmiş ve bu ekmeklerin fiziksel, yapısal, renk ve tekstürel özellikleri ölçülmüştür. İncelenen ekmek nitelikleri bakımından, farklı tav muameleleri arasında çok sınırlı ölçüde bir farklılık oluştuğu, kayda değer belirgin bir değişimin ortaya çıkmadığı $(\mathrm{p}>0.05)$ saptanmıştır. Bulgular, tavlama prosesinde buğdaya verilen su miktarının kademeli olarak iki defada verilmesinin un niteliklerini geliştirme noktasında yarar sağladığına dair ipuçları içermektedir. Ancak bu konuda yapılacak olan daha başka çalışmalara ihtiyaç olduğu açıktır.

Anahtar Kelimeler: Ekmeklik buğday, Ekmek kalitesi, İki aşamalı tavlama, Tavlama prosesi.

\section{The Effects of Two-Step Tempering Treatment on the Bread Properties of Flour in Bread Wheat (Triticum aestivum L.)}

\begin{abstract}
In this study, the effects of two-step tempering treatment on the bread quality of wheat were investigated. Two wheat varieties (Adana99 and Russian) with different variety properties were used in the research. Each wheat variety was subjected to four different tempering treatments. These treatments were; a. no tempering (=control), b. single-step tempering for 24 hours, c. single-step tempering for 48 hours and d. two-step tempering for 48 hours. Following the treatment procedures, flour samples obtained from wheat samples fed to the mill were subjected to bread making experiments by a standard method and the physical, structural, color and textural properties of these breads were measured. It was found that there was a very limited difference between the different tempering treatments in terms of the investigated bread qualities, and no remarkable change was detected $(\mathrm{p}>0.05)$. The findings include clues that, the fact that water is added to the wheat in the tempering process in two steps improved the flour quality. However, it is clear that further studies are required on this subject.
\end{abstract}

Keywords: Bread wheat, Bread quality, Two-step tempering, Tempering process.

\footnotetext{
* Sorumlu Yazar: Osmaniye Korkut Ata Üniversitesi, Mühendislik Fakültesi, Gıda Mühendisliği Bölümü, Osmaniye, Türkiye, ORCID: 0000-00015873-5462, hdizlek@,osmaniye.edu.tr
} 


\section{Giriş}

Ülkemizde gerek ekim alanı gerekse üretim miktarı bakımından tahıllar içerisinde ilk sırada yer alan buğday (2017 yılı verilerine göre 21.5 milyon ton; ZMO, 2018; TÜİK, 2019); tarımının kolay yapılabilmesi, çok çeşitli gıdalara dönüşüm uygunluğu ve beslenmedeki rolü itibariyle önemli bir kültür bitkisidir (Pyler, 1988). Ülkemizde buğday bazlı ara ürünlerden (un, irmik, nişasta, kepek, ruşeym, tam buğday unu ve bulgur gibi) üretilen mamul ürünlerin (ekmek, makarna, kek, pasta, bisküvi, kurabiye, simit, bazlama, börek, bulgur pilavı gibi) tüketimi günlük diyetimizde ilk sırada yer almakta ve bu gıdalar diğer gıda gruplarına göre belirgin olarak daha yüksek düzeyde talep görmektedir. Bunda, tahılların temel enerji kaynağı olan karbonhidratlar bakımından çok zengin olmasının yanısıra, ülkemiz insanının unlu mamullere duyduğu yüksek ilginin önemli rol üstlendiği düşünülmektedir (Dizlek, 2010).

Buğday tanesi anatomik olarak diştan içe doğru kabuk (\%13-17), embriyo (\%2-3) ve endosperm tabakalarından (\%80-85) oluşur (Hoseney, 1986). Buğday değirmenciliğinde amaç endospermi (un veya irmiği) kabuk ve embriyo tabakalarından (kepekten) ayırmaktır. Değirmencilikte buğdayın un ve irmiğe işlenmesinde yer alan prosesler başlıca 3 grup altında toplanabilir: 1) Hazırlık işlemleri (buğdayın; alımı ve depolanması, temizlenerek yabancı maddelerinden ayrılması, paçal yapılması, gerekiyorsa yıkanması ve tavlanması), 2) Öğütme işlemleri (kırma ve inceltme valsleri ile elek takımları ve irmik-kepek saflaştırma düzenekleri yardımıyla) ve 3) Un depolama ve paçal işlemleri (Elgün ve Ertugay, 1997). Tüm bu işlem basamakları, elde edilecek olan değirmencilik ürünlerinin (un, irmik, kepek, razmol, bon kalite gibi) kalitatif ve kantitatif özelliklerine etki etmektedir. Bununla beraber, hazırlık işlemlerinde ortaya konulan emek ve gösterilen titizlik, paritesi yüksek un ve irmik elde etmenin yanında, işletmenin enerji sarfiyatını azaltmakta ve vals-elek sistemlerinin daha uzun süreli ve randımanlı bir biçimde kullanılmasına neden olmaktadır. Bu nedenlerden dolayı değirmencilikte ögütme öncesinde uygulanan hazırlık işlemleri, üzerinde önemle durulması gereken proseslerdir. Bu işlemler içerisinde tavlama, özel ve ayrıcalıklı bir yere sahiptir.

Un değirmenciliğinde buğdayı kırmak ve boyut küçülterek arzu edilen materyali (un, irmik ve nişasta gibi) ortaya çıkarmak için valslere beslemeden önce öğ̈̈tmeye hazırlık aşamasında buğdaya uygulanan en son işlem basamağı olan tavlama; buğdaya soğuk veya sıcak su eklenmesi ve bu suyu tanenin emmesi için buğday kitlesinin bir müddet dinlendirilmesi işlemidir. Tanımından da anlaşılacağı üzere, tavlama işleminde ilkin buğday kitlesinin nem içeriği belirlenmekte, sonra buna uygun su verilmektedir. Bu işlemden sonra buğday, ögütme için optimum nem dağılımına ve ögütme özelliklerine ulaşana kadar ambarlarda (tav silolarında) dinlenmeye bırakılmaktadır (Keskinoğlu ve ark., 2001). Bu suretle, çok rijid bir yapıya sahip olan buğday kabuğu elastik bir yapıya kavuşarak daha kolay kırılır (işletmenin enerji sarfiyatı azalır) ve birbirine sıkı biçimde bağlı olan tanenin kabuk ve endosperm tabakaları arasındaki bağlar gevşetilerek unun kepekten ayrıştırılması daha kolay bir hal alır (Yoo ve ark., 2009; MacRitchie, 2010). Tavlama üzerinde; tane sertliği, buğdayın başlangıç nemi, uygulanacak süre, su miktarı ve sıcaklığı ile elde edilmek istenilen ara ürünün nitelik ve niceliği gibi birçok etmen etkilidir. Dizlek ve Gül (2007) ve Dıraman ve ark. (2013), tavlama prosesinin süne hasarına uğramış bugdayların ekmeklik kalitesini ıslah edebildiğini; Dizlek ve İslamoğlu (2010) ise, süne-kımıl zararı görmüş buğdayların ekmeklik kalitesini düzeltecek veya zararı en aza indirecek uygulamaların geliștirilmesi (uygun tavlama normlarının buğdaya muamele edilmesi) halinde (Dıraman, 2010; Dıraman ve ark., 2013), bu buğdaylarin ekonomiye tekrar kazandırılabileceğini bildirmişlerdir.

Ülkemizde her bölgede yetiştirilebilen buğday yaygın olarak İç Anadolu Bölgesi’nde üretilmektedir. Ülkemizde y1llık olarak üretilen 30-35 milyon ton hububatın 20-22 milyon tonunu (\%65-70’ini) yalnız başına buğday oluşturmaktadır. Dünya nüfusuna oranı yaklaşık \%1 olan ülkemiz, dünya buğday üretiminde $\% 3$ civarında bir paya sahiptir. Buğday ve buğday unu üretimi/ihracatı/ithalatı konularında ülkemiz dünya ülkeleri arasında önemli bir pozisyona sahiptir ve bölgesel anlamda güçlü bir aktördür. Bu bakımdan stratejik öneme de sahip olan buğday (unu) üzerine ülkemizde yapılan bilimsel eksenli çalışmaların ayrı bir öneme sahip olduğu açıktır. Ülkemizde un ihracatı son yıllarda giderek artan bir ivmeye sahiptir. Bundan dolayı buğday ithalatı yapmaya başlayan, ancak bu buğdayı özelde una ve bazen irmiğe işleyerek katma değer sağlayan değirmencilik sektörünün bilhassa Ortadoğu ülkelerine yapmış olduğu un ihracatında, ithalatçılar tarafından üzerinde önemle durulan bir konu unun renginin bembeyaz olmasıdır. Bu nedenle çalışmada, un ihracatımıza destek sunması noktasında önem arz edebilecek bir uygulamaya (buğdayın iki kez tavlanması) yer verilmiş, bu suretle pilot ölçekte - renk ve kül değeri düşük, paritesi yüksek un üretilmeye çalışılmıştır. Yine, günümüze kadar tavlama ile ilgili yapılan çalışmalarda daha çok tavlama süresi, tavlama suyu sıcaklı̆̆ı ve farklı tavlama metotları (1lık, sicak, buharlı, mikrodalga, ultrason vb.) üzerinde durulmuştur (Butcher ve Stenvert, 1973; Stenvert ve Kingswood, 1976; Moss, 1977; Finney ve Bolte, 1985; Ibanoglu, 2001; Keskinoğlu ve ark., 2002; Sünter, 2003; Kweon ve ark., 2009; Diraman, 2010; Diraman ve ark., 2013; Warechowska ve ark., 2016). Bu çalışmada, sertlik derecesi farklı olan iki çeşit ekmeklik buğdaya klasik (bir kez) tavlamanın yanı sıra iki kez tavlama işlemi uygulanmıştır. Bu suretle ekmeklik buğdaylara iki kez uygulanan tavlama işleminin unun ekmeklik özelliklerine etkisi araştırılmıştır.

\section{Materyal ve Metot}

\subsection{Materyal}

Araştırmanın materyalini buğday, un, su, maya ve tuz oluşturmuştur. Kullanılan materyalin özellikleri aşağıda ayrı ayrı belirtilmiştir.

Buğday: Araștırmada yerli, orta sert “Adana-99" ve Ukrayna menșeli Rusya'dan ithal edilen düşük proteinli, yumuşak "Rus" olmak üzere 2 farklı ekmeklik buğday (Triticum aestivum L.) çeşidi kullanılmıştır. Söz konusu buğday örneklerinin her ikisi 2017 ürünü olup; Adana-99 çeşidi Osmaniye'de faaliyet gösteren İslamoğlu Ticaret’ten, Rus çeşidi ise Sunar Özlem Un Fabrikasından (Osmaniye) 100'er kg olarak temin edilmiştir. Söz konusu buğday kitlelerinden numune alma yöntemine (TS EN ISO 24333; TSE, 2012) uygun olarak alınan örnekler 50 kg’lık jüt çuvallara doldurularak analiz edilinceye ve ögütülünceye kadar Osmaniye Korkut Ata Üniversitesi Merkezi Araştırma Laboratuvarına nakliye edilmiş ve soğuk hava deposunda $\left(+4{ }^{0} \mathrm{C}\right)$ muhafaza edilmişlerdir. Araştırmanın temelini oluşturan 
buğday örneklerinin ekmekçilik açısından önemli olan fiziksel ve kimyasal özellikleri (Uluöz, 1965; Atlı ve ark., 1988; Elgün ve ark., 2005; AACCI Metot 39-11.01 ve 39-25.01; AACCI, 2010) Çizelge 1'de, teknolojik özellikleri Çizelge 2'de verilmiştir.

Çizelge 1. Araştırmada Kullanılan 2 Farklı Buğday Örneğinin Fiziksel ve Kimyasal Özelliklerine İlişkin Ortalama Veriler

\begin{tabular}{|c|c|c|c|c|c|c|c|c|c|c|}
\hline $\begin{array}{l}\text { Buğday } \\
\text { çeşidi }\end{array}$ & $\begin{array}{c}\text { Süne Emgili } \\
\text { Tane Oranı } \\
(\%)\end{array}$ & $\begin{array}{l}1000 \text { Tane } \\
\text { Ağırlığı } \\
(\text { g) } \\
(1)\end{array}$ & $\begin{array}{c}\text { Hektolitre } \\
\text { Ağırlığı } \\
\text { (kg) }\end{array}$ & $\begin{array}{c}\text { Un } \\
\text { Verimi } \\
(\%)^{(2)}\end{array}$ & $\begin{array}{c}\text { Sert } \\
\text { Tane } \\
\text { Oranı } \\
(\%)\end{array}$ & $\begin{array}{l}\text { Dönme } \\
\text { Tane } \\
\text { Oranı } \\
(\%)\end{array}$ & $\begin{array}{c}\text { Yumuşak } \\
\text { Tane } \\
\text { Oranı } \\
(\%)\end{array}$ & $\begin{array}{c}\text { Nem } \\
\text { Miktarı } \\
(\%)\end{array}$ & $\begin{array}{c}\text { Protein } \\
\text { Miktarı } \\
\\
(\%)\end{array}$ & $\begin{array}{c}\text { Nişasta } \\
\text { Miktarı } \\
(\%)\end{array}$ \\
\hline Adana-99 & 1.92 & 37.0 & 83.1 & 52.3 & 45 & 49 & 6 & 12.8 & 13.0 & 62 \\
\hline Rus & 2.15 & 40.5 & 82.7 & 61.3 & 15 & 39 & 46 & 14.1 & 10.7 & 63 \\
\hline
\end{tabular}

(1) 1000 tane ağırlık değerleri kuru madde üzerinden verilmiştir.

${ }^{(2)} \mathrm{CD} 1$ değirmeninde 3 kırma, 2 inceltme valsinden geçirilerek öğütülmüş ve değirmenin kendi eleğinden elenmek suretiyle hesaplanmıştır.

Çizelge 2. Araştırmada Kullanılan 2 Farklı Buğday Örneğine Ait Unlarin Teknolojik Özelliklerine İlişskin Ortalama Veriler

\begin{tabular}{lccccc}
\hline $\begin{array}{l}\text { Buğday } \\
\text { ceşidi }\end{array}$ & $\begin{array}{c}\text { Yaş Gluten } \\
\text { Miktarı } \\
(\%)\end{array}$ & $\begin{array}{c}\text { Kuru Gluten } \\
\text { Miktarı } \\
(\%)\end{array}$ & $\begin{array}{c}\text { Sedimantasyon } \\
\text { Değeri } \\
(\mathbf{m L})\end{array}$ & $\begin{array}{c}\text { Gecikmeli } \\
\text { Sedimantasyon Değeri } \\
(\mathbf{m L})\end{array}$ & $\begin{array}{c}\text { Düşsme SayıSI } \\
\text { Değeri } \\
(\mathbf{s})\end{array}$ \\
\hline Adana-99 & 28.5 & 9.2 & 38 & 31 & 337 \\
Rus & 21.6 & 6.7 & 32 & 20 & 356 \\
\hline
\end{tabular}

Un: Araştırmada, sertlik derecesi farklı iki çeşit buğdaya değişik tavlama prosesleri uygulanması ve takiben buğdayların öğütülmesi sonucunda elde edilen unlar kullanılmıştır. Bu unların elde edilmesinde uygulanan yöntem, çalışmanın "Yöntem" kısmında ayrıntılı olarak açıklanmıştır.

Su: Buğdayların tavlanmasında Osmaniye Korkut Ata Üniversitesi, ekmek yapma denemelerinde ise Çukurova Üniversitesi yerleşkesi su şebekelerinden temin edilen içme suyu kullanılmıştır.

Maya: Araştırmada, "Pakmaya” firmasınca (Kartepe/Kocaeli) üretilen pres yaş maya (TS 3522; TSE, 2015) kullanılmıştır.

Tuz: Osmaniye piyasasından temin edilen "Billur” marka, iyot içermeyen rafine kristal tuz (TS 933; TSE, 2003) kullanılmıştır.

\subsection{Metot}

\subsubsection{Deneme Buğday Gruplarının Oluşturulması}

Araştırmada kullanılan Adana-99 buğdayının tavlama ile hedef nem miktarı \%17, Rus buğdayının ise \%16.5 olacak şekilde ayarlama yapılmıştır. Buğday kitlelerine katılacak tavlama suyu miktarı AACCI Metot 26-95.01 (AACCI, 2010)'e göre hesaplanmıştır. Buğday örneklerinin tavlanmasında musluk suyu kullanılmış ve örnekler soğuk tavlanmıştır. Bu araştırma kapsamında, nitelikleri birbirinden farklı olan 2 ekmeklik buğday çeşidinin her birinde aşağıda belirtilen farklı tavlama muameleleri uygulanarak deneme materyali ve deseni oluşturulmuştur:

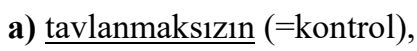

b) 24 saat süre ile klasik (bir kez) tavlama (Hedef neme göre hesaplanan su miktarı buğdaylara bir seferde verilmiş ve 24 saat süre ile tavlanmıştır),

c) 48 saat süre ile klasik (bir kez) tavlama (Hedef neme göre hesaplanan su miktarı buğdaylara bir seferde verilmiş ve 48 saat süre ile tavlanmıştır),

d) 48 saat süre ile iki kez tavlama (Adana-99 ve Rus buğdaylarına başlangıçta sırasıyla $\% 15$ ve $\% 15.5$ olacak şekilde birinci tav suyu verilmiş ve 24 saat dinlendirilmiştir. 24 saat süre bitiminde Adana-99 ve Rus buğdayında sırasıyla hedef nem \%17 ve \%16.5 olacak şekilde ikinci tav suyu verilmiş ve yine 24 saat dinlendirilmiştir (özetle bu muamelede buğday örnekleri 2 kez tavlanmış ve buğdayların nihai tav nemi $b$ ve c maddesindeki yüzdeye ayarlanmıştır.).

\subsection{2. Öğ̈̈̈tme İslemi}

Buğday örnekleri; ilk 3'ü kırma, son 2'si inceltme valsi olmak üzere toplam 5 valsli “Chopin” marka "CD1" model laboratuvar tipi tavlı buğday öğütme değirmeninde (Chopin Technologies, Paris, Fransa) öğütülerek una işlenmişlerdir. Deneme desenine uygun şekilde gerekli su miktarı verilen ve belli bir süre (a imli numuneler için 0 saat; $b$ imli numuneler için 24 saat; $\mathrm{c}$ ve d imli numuneler için 48 saat) dinlendirilen buğday örnekleri laboratuvar tipi valsli değirmende öğütülerek una işlenmişlerdir. Değirmen, kırma ve redüksiyon olmak üzere iki kısımdan oluşmaktadır. Temizlenmiş ve tavlanmış buğdaylar önce kırma sistemine verilerek kırılmış, buğday kırmasından irmik, kaba kepek ve biraz da kırma unu ayrılmıştır. Ana ürün olarak elde edilen irmik, redüksiyon sisteminde öğütülerek una indirgenmiş ve ince kepek yan ürün olarak ayrılmıştır. Ayrılan ince kepek ikinci defa redüksiyon sisteminden geçirilerek toplam un $($ kırma unu +1 . redüksiyon unu +2 . redüksiyon unu) elde edilmişsir. Kırma ve redüksiyon sistemlerinden elde edilen un örnekleri 
tartılmış, başlangıçta öğütülen temizlenmiş ve tavlanmış buğday miktarına oranlanmak suretiyle un randımanları \% olarak hesaplanmıştır (Elgün ve ark., 2005; Çizelge 1).

\subsubsection{Ekmek Yapma Denemeleri}

Ekmek yapma denemelerinde güdülen amaç, çalışmanın temel sacayağını oluşturan farklı tavlama muamelelerinin ekmek kalitesi üzerine etkilerini belirlemektir. Bu suretle buğdaylara uygulanan farklı tavlama işlemlerinin nihai ürün olan ekmekteki olası etkileri ortaya konulmaya çalışılmıştır. Çünkü bir buğdayın ekmeklik kalitesi fiziksel, kimyasal, fizikokimyasal ve reolojik testlerle önemli ölçüde ortaya konulsa da söz konusu buğdaydan elde edilen unun gerçek ekmeklik kalitesi bu unun ancak standart bir metotla ekmeğe işlenmesi ve üretilen ekmeklerin analitik olarak bazı özelliklerinin belirlenmesi ile ortaya konulabilmektedir (Uluöz, 1965; Altan, 1986; Dizlek ve Gül, 2009).

Araştırmada farklı tav muamelelerinin buğdayın ekmeklik kalitesine olan etkisinin net bir biçimde ortaya konulması hedeflenmiş ve bu nedenle hamur formülünde sadece temel hamur bileşenlerine (un, su, maya ve tuz) yer verilmiş, hiçbir katkı maddesi kullanılmamıştır. "2.1.1. Deneme Buğday Gruplarının Oluşturulması" başlığı altında verilen ve harf imleriyle kodlanan muamelelerden a, b, c ve d imleriyle gösterilen numunelere ait unlar ile ekmek yapma denemeleri gerçekleştirilmiştir. Böylece her iki buğday çeşidinde de 4 ayrı tav muamelesi sonucu elde edilen unlar ile ekmek üretimleri yapılmış ve bu muameleler mukayese edilmiş̧ir. Tüm ekmek yapma denemeleri, tavlı ya da tavsız buğday örneklerinin öğütülmesini izleyen 6 . ayda yapılmıştır. Ekmek yapma çalışmalarında uygulanan deneme deseni Çizelge 3'de verilmiş, deneme koşulları ve uygulanan yöntem aşağıda açıklanmıştır.

Çizelge 3. Araştırmada Uygulanan Ekmek Yapımına Ait Deneme Deseni ${ }^{(1)}$

\begin{tabular}{lccc}
\hline $\begin{array}{l}\text { Tav süresi } \\
\text { (saat) }\end{array}$ & $\begin{array}{c}\text { Tav sayısı } \\
\text { (adet) }\end{array}$ & Bdana-99 & Buğday Örneği \\
\hline 0 (tavsiz=kontrol) & 0 & $\mathrm{x}$ & Rus \\
24 & 1 & $\mathrm{x}$ & $\mathrm{x}$ \\
48 & 1 & $\mathrm{x}$ & $\mathrm{x}$ \\
48 & 2 & $\mathrm{x}$ & $\mathrm{x}$ \\
\hline
\end{tabular}

${ }^{(1)}$ Her bir deneme için ayrı ayrı hazırlanan hamur formülü sabit olup şu bileşenlerden oluşmaktadır: Un $(100 \mathrm{~g})+\mathrm{Su}$ (Farinograf cihazında belirlenen su kaldırma miktarı kadar) + Maya (3 g) + Tuz (1.5 g)

\subsubsection{Ekmek Yapma Metodu}

Ekmek yapma denemeleri, Çukurova Üniversitesi Ziraat Fakültesi Gıda Mühendisliği Bölümü Pilot Fırın Ünitesinde ve Tahıl İşleme Teknolojisi Laboratuvarında mekanik hamur olgunlaştırma yöntemi esas alınarak (Dizlek ve Özer, 2017) gerçekleştirilmiştir. Ekmek yapımında uygulanan işlem basamakları Şekil 1'de şematize edilmiştir. Ekmek yapımında, un esasına göre, sabit bileşenler olarak; "farinograf cihazında belirlenen su kaldırma miktarı kadar su, \%3 maya ve \%1.5 tuz" kullanılmıştır.

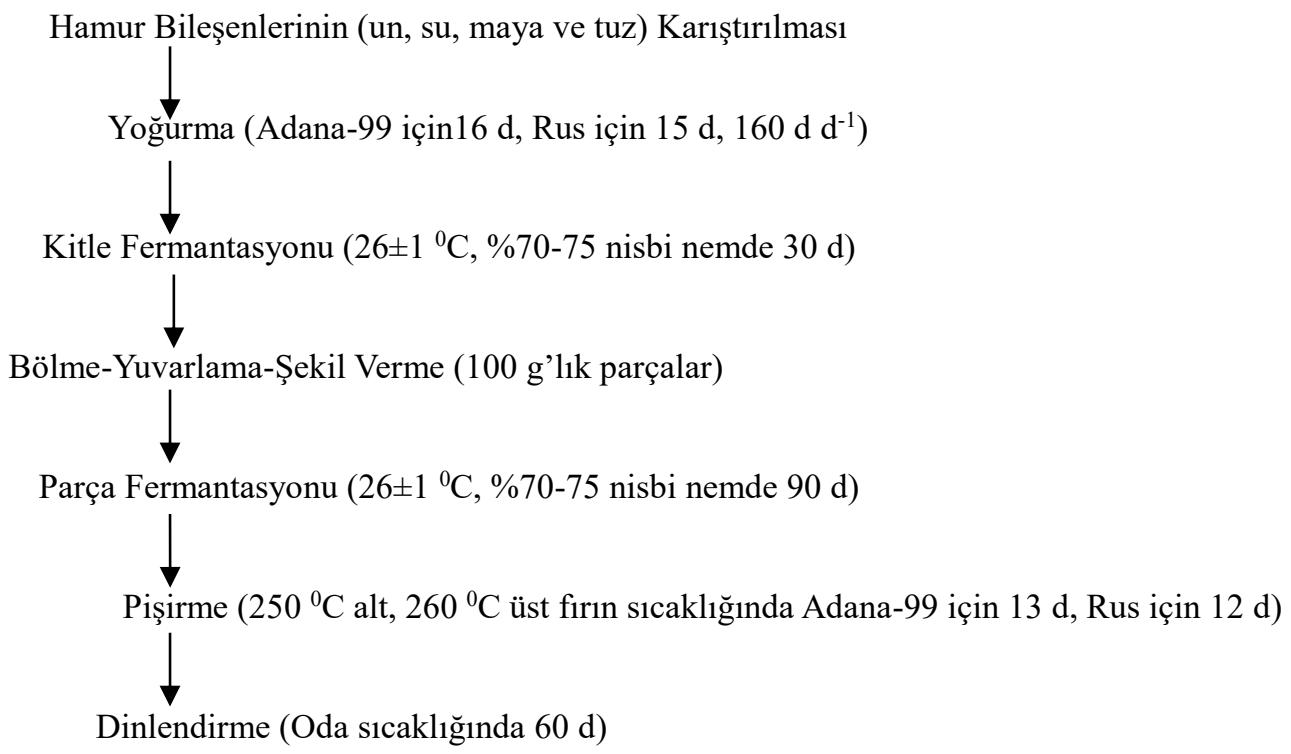

Şekil 1. Ekmek Yapımında Uygulanan İşlem Basamakları 
Ekmek denemelerinde; Günsa Makine Sanayi A.Ș. (İzmir, Türkiye) tarafından üretilen $1 \mathrm{~kg}$ un kapasiteli ve $160 \mathrm{~d} \mathrm{~d}^{-1}$ hızındaki spiral milli yoğurma makinesi, Çukurova Üniversitesi Döner Sermaye Atölyesinde 1sı yalıtımına sahip malzemeden yapılmış, 1sıtma donanımlı ve buhar üniteli fermantasyon kabini, "Fimak" marka "EKF 60.80" model taş tabanlı firın (Konya, Türkiye) kullanılmıştır.

\subsubsection{Analiz Metotlart}

\subsubsection{Ekmek Örneklerine Uygulanan Analizler}

Denemelerde üretilen ekmeklerin hacim ve ekmek verimleri (Uluöz, 1965), spesifik hacim (Elgün ve ark., 2002), yükseklik, taban çap1 ve yükseklik/taban çapı (Hoseney, 1986; yayılma oranı testinin kısmen modifiye edilmesi suretiyle), pişme kaybı (Altan, 1986), gözenek (TS 5000; TSE, 2010; 8 puan üzerinden), tekstürel (sıkılık ve yaylana bilirlik; [AACCI Metot 74-09.01; AACCI, 2010]) ve renk özellikleri (L*, $a^{*}, b^{*}$, Hue ve Chroma değerleri; Francis, 1998) belirlenmiştir.

Üretilen ekmek örneklerinin özgül hacim değerleri; hardal tohumu ile yer değiştirme metoduna göre belirlenen ekmek hacminin $\left(\mathrm{cm}^{3}\right)$ ekmek ağırlığına $(\mathrm{g})$ oranlanması suretiyle hesaplanmıştır. Başlangıçta kullanılan hamur ağırlığı $(100 \mathrm{~g})$ ile elde edilen ekmek ağırlı̆̆ arasındaki fark pişme kaybı değeri olarak hesaplanmış ve \% olarak ifade edilmiştir. \%14 nem esasına göre $100 \mathrm{~g}$ undan elde edilen ekmeğin ağırlığı ekmek verimi, yine aynı esasa göre $100 \mathrm{~g}$ undan yapılan ekmeğin hacmi hacim verimi olarak hesaplanmıştır. Her 2 verim değerinin belirlenmesinde hamur formülü ve formüldeki un miktarı göz önüne alınarak orantı yoluyla hesaplama yapılmıştır. Yükseklik-taban çapı analizi ise 10 adet ekmek örneğinin eninin ve boyunun kumpas aleti yardımıyla ölçülmesi suretiyle yapılmıştır. Gözenek değerlerinin belirlenmesi, TS 5000 (TSE, 2010) ekmek standardında verilen ekmek içi gözenek yapılarına ait şekillerin incelenmesi suretiyle yapılmıştır. Tekstürel özelliklerin belirlenmesi işlemi "Stable Micro Systems" marka tekstür cihazı ile (TA-XT Plus Texture Analyser, Vienna Court, İngiltere) yapılmıştır. Bunun için proba uygun biçimde kesilen her bir ekmek diliminin üç ayrı noktasından ölçüm alınmış ve "Bulgular" kısmında ortalama değerler verilmiş̧ir. Tekstür analizinin uygulanmasında kullanılan parametreler şu şekildedir; Test Modu: Sıkıştırma, Pre-test speed: $1 \mathrm{~mm} \mathrm{~s}^{-1}$, Test speed: $1 \mathrm{~mm} \mathrm{~s}^{-1}$, Post-test speed:10 mm s${ }^{-1}$, Strain: $\% 25$, Hold time: $60 \mathrm{~s}$, Trigger force: $5 \mathrm{~g}$, Probe; P/36R; $36 \mathrm{~mm}$ çapında, alüminyum). Renk ölçümleri ekmeklerin kabuğunda -3 ayrı noktada - Konica Minolta Chroma meter CR-400 model (Tokyo, Japonya) renk ölçüm cihazı ile yapılmış; L*, a*, b*, Hue ve Chroma değerleri ölçülmüştür (Francis, 1998). Analizler ekmeklerin firın çıkışından 1 saat sonra yapılmıştır.

\subsubsection{2. İstatistiksel Analizler}

Buğday örneklerine uygulanan farklı tavlama muameleleri ile analizler iki kez tekrar edilmiştir. Denemelerde üretilen ekmeklerin ölçülen tüm özelliklerine ilişkin olarak elde edilen verilere öncelikle varyans analizi uygulanmış, sonra önemli bulunan değerler Duncan çoklu karşılaştırma testine tabi tutulmuştur. İstatistiksel analizler, "SAS" istatistik enstitüsünce geliştirilen ve aynı adı taşıyan istatistik paket programı (The SAS System for Windows v6.12; SAS Institute, 1982) kullanılarak yapılmıştır.

\section{Araştırma Sonuçları ve Tartışma}

Farklı tavlama muameleleri uygulanmış buğdayların unlarından standart bir yöntemle üretilen ekmeklerin bazı kalitatif özellikleri Çizelge 4'de, renk ve tekstürel özellikleri Çizelge 5'de, resimleri Şekil 2 ve 3'de verilmiştir.

Çizelge 4. Farklı Tavlama Muameleleri İle Öğ̈̈tülen Buğdayların Unlarından Üretilen Ekmeklerin Bazı Özellikleri ${ }^{(1)}$

\begin{tabular}{|c|c|c|c|c|c|c|c|c|c|}
\hline $\begin{array}{l}\text { Buğday } \\
\text { çeşidi }\end{array}$ & Tav Muamelesi & $\begin{array}{c}\text { Ekmek } \\
\text { Verimi } \\
\left(\mathrm{g} 100 \mathrm{~g} \mathrm{un}^{-1}\right) \\
\end{array}$ & $\begin{array}{c}\text { Pişme } \\
\text { Kaybi } \\
(\%)\end{array}$ & $\begin{array}{c}\text { Yükseklik } \\
\text { (mm) }\end{array}$ & $\begin{array}{l}\text { Taban } \\
\text { Çapı } \\
(\mathrm{mm}) \\
\end{array}$ & $\frac{\text { Yükseklik }}{\text { Taban Çapı }}$ & $\begin{array}{c}\text { Hacim } \\
\text { Verimi } \\
\left(\mathrm{cm}^{3} 100 \mathrm{~g} \mathrm{un}^{-1}\right)\end{array}$ & $\begin{array}{c}\begin{array}{c}\text { Özgül } \\
\text { Hacim } \\
\left(\mathrm{cm}^{3} \mathrm{~g}^{-1}\right)\end{array} \\
\end{array}$ & $\begin{array}{c}\text { Gözenek } \\
\text { Değeri } \\
\text { (0-8 Puan) }\end{array}$ \\
\hline \multirow[t]{3}{*}{ Adana-99 } & Tavsız (kontrol) & $144.9^{a}$ & $12.2^{\mathrm{a}}$ & $65.2^{a}$ & $89.9^{a}$ & $0.73^{\mathrm{b}}$ & $475^{\mathrm{a}}$ & $3.28^{\mathrm{a}}$ & 6.5 \\
\hline & 48 saat bir kez tavlı & $144.3^{\mathrm{ab}}$ & $11.7^{\mathrm{b}}$ & $63.2^{\mathrm{ab}}$ & $88.1^{\mathrm{a}}$ & $0.72^{\mathrm{b}}$ & $463^{\mathrm{a}}$ & $3.21^{\mathrm{a}}$ & 6.6 \\
\hline & 48 saat iki kez tavlı & $144.0^{\mathrm{ab}}$ & $11.4^{\mathrm{c}}$ & $67.1^{\mathrm{a}}$ & $89.1^{\mathrm{a}}$ & $0.75^{a}$ & $482^{\mathrm{a}}$ & $3.35^{\mathrm{a}}$ & 6.7 \\
\hline \multirow{2}{*}{ Rus } & 48 saat bir kez tavlı & $142.9^{\mathrm{a}}$ & $11.1^{\mathrm{b}}$ & $57.5^{\mathrm{b}}$ & $87.4^{\mathrm{b}}$ & $0.66^{\mathrm{b}}$ & $452^{\mathrm{c}}$ & $3.16^{\mathrm{c}}$ & $7.0^{\mathrm{a}}$ \\
\hline & 48 saat iki kez tavlı & $140.3^{\mathrm{b}}$ & $12.1^{\mathrm{a}}$ & $58.7^{\mathrm{b}}$ & $88.6^{\mathrm{ab}}$ & $0.66^{\mathrm{b}}$ & $478^{b}$ & $3.40^{\mathrm{b}}$ & $7.3^{\mathrm{a}}$ \\
\hline
\end{tabular}

(1) Çizelgede aynı buğday örneği için aynı sütunda farklı harfle gösterilen değerler arasındaki farklar 0.05 güven sınırına göre önemlidir.

Çizelge 4'e ait verilerin bir arada incelenmesiyle, ele alınan ekmek nitelikleri bakımından, farklı tav muameleleri arasında çok sınırlı ölçüde bir farklılık oluştuğu, kayda değer bir değişimin ortaya çıkmadığı saptanmıștır. Adana-99 çeşidinde tav süresi ve sayısının artmasına bağlı olarak ekmeklerin pişme kaybı değerleri azalmıştır. Ekmek verimi değerlerinde de daha sınırlı düzeyde olmak kaydı ile benzer bir etkiden söz edilebilir. Bu durumun ekmek yapımında un örneklerine verilen su miktarlarının farklı olmasından kaynaklanabileceği düşünülmektedir. Nitekim farinograf su kaldırma değeri dikkate alınarak reçete edilen hamur formülünde Adana99 çeşidinin kontrol örneğine \%60.6 oranında su ilave edilmiş oysa 48 saat süre ile iki kez tavlanan buğdaya ait una ise $\% 2.5$ oranında daha az su katılarak \%58.1 oranında su verilmiştir. Ekmek örneklerinin yükseklik, taban çapı, hacim verimi ve özgül hacim değerleri bakımından 24 saat süre ile bir kez tavlı olan numunenin en kötü niteliklere sahip olduğu, diğer üç farklı muameleye ait ekmek örnekleri arasında kayda değer bir farklılığın ortaya çıkmadığı belirlenmiştir. 


\section{ADANA-99 Buğdayı}

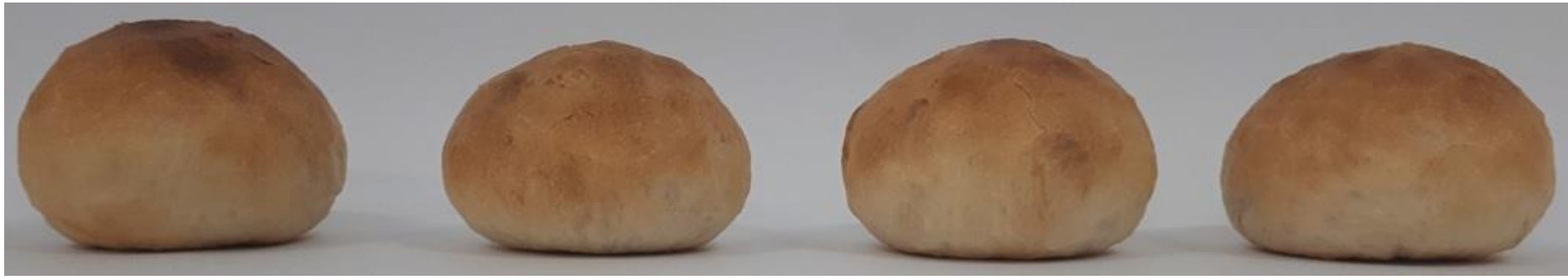

Kontrol

24 saat bir kez tavlı

48 saat bir kez tavlı

48 saat iki kez tavlı

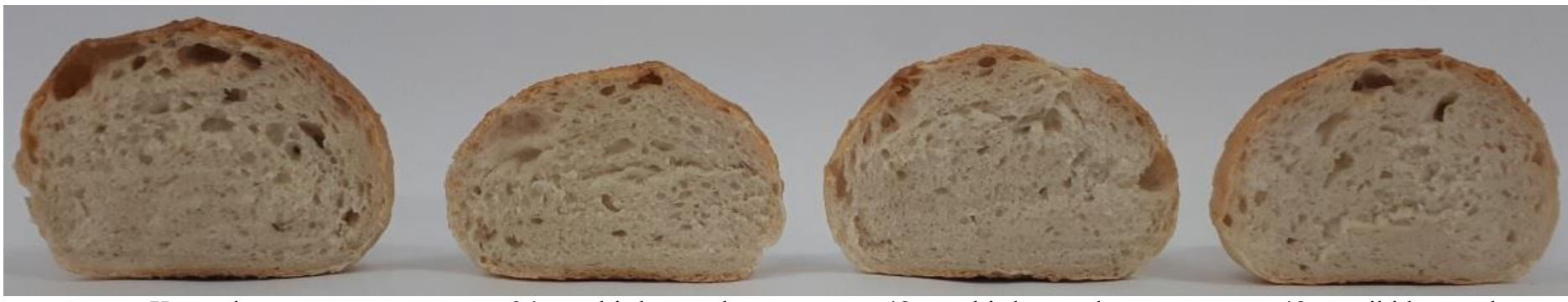

Kontrol

24 saat bir kez tavlı

48 saat bir kez tavlı

48 saat iki kez tavlı

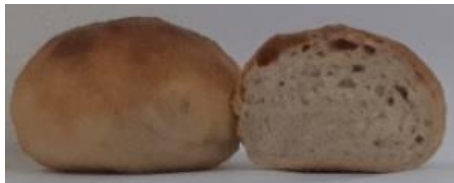

Kontrol

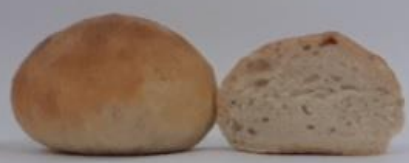

24 saat bir kez tavlı

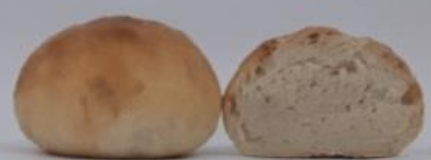

48 saat bir kez tavlı

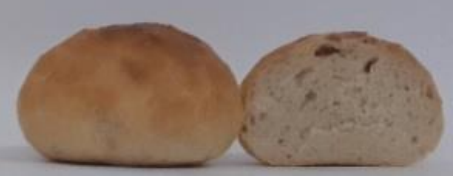

48 saat iki kez tavlı

Şekil 2. Farklı Tavlama Muameleleri İle Öğ̈̈tülen Adana-99 Buğdayının Unlarıyla Üretilen Ekmek Örnekleri

\section{RUS Bŭ̆dayı}

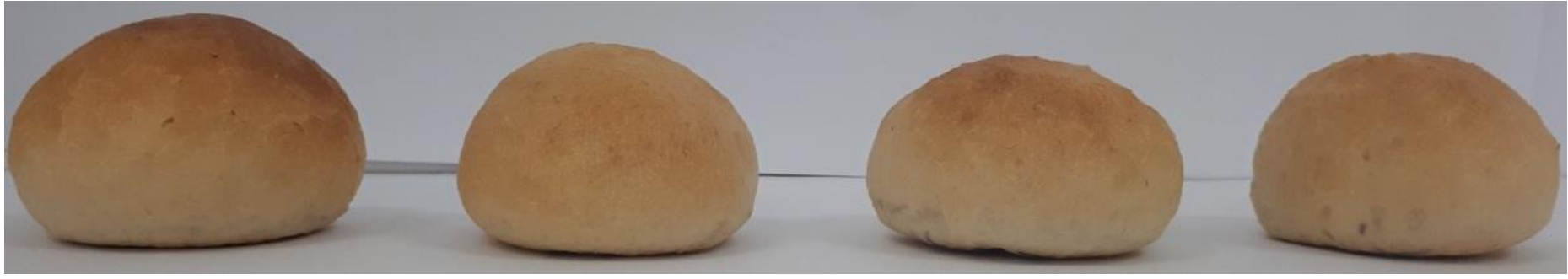

Kontrol

24 saat bir kez tavlı

48 saat bir kez tavlı

48 saat iki kez tavlı

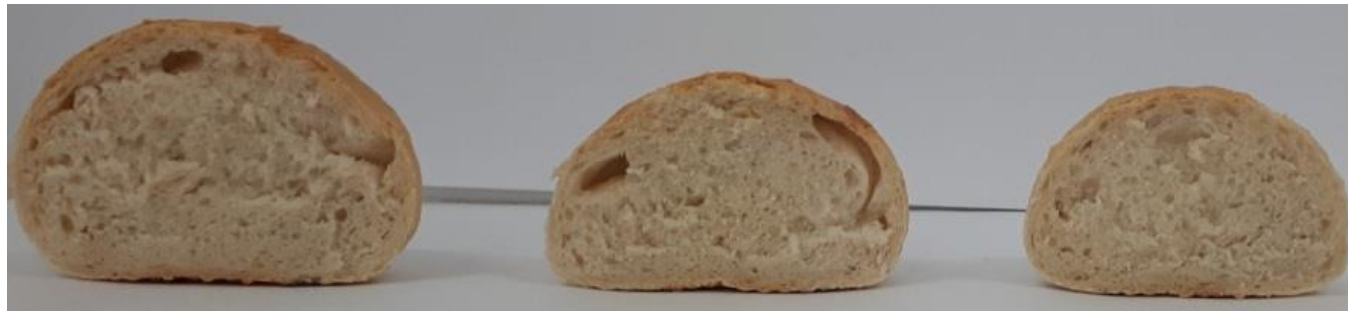

Kontrol

24 saat bir kez tavlı

48 saat bir kez tavlı

48 saat iki kez tavlı

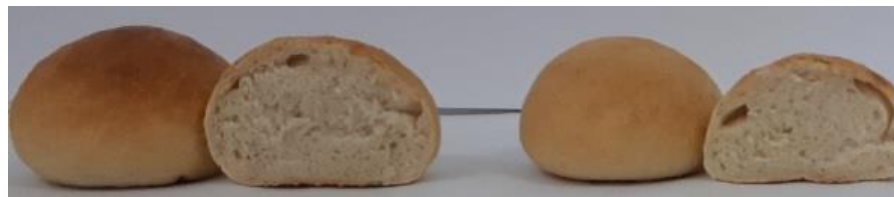

Kontrol
24 saat bir kez tavlı

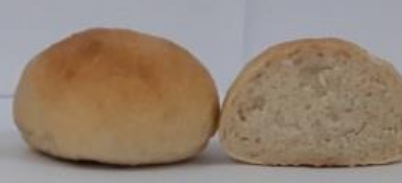

48 saat bir kez tavlı

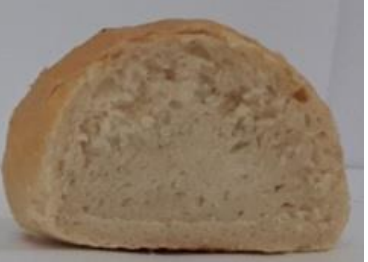

Şekil 3. Farklı Tavlama Muameleleri İle Öğ̈̈tülen Rus Buğdayının Unlarıyla Üretilen Ekmek Örnekleri 
Rus buğday çeşidinde tavlanmamış buğday örneğine ait ekmek numunesi gözenek yapısı ve pişme kaybı değeri haricinde kalan diğer analitik ölçümler bakımından en üstün değere sahiptir. Bu numuneye ait ekmeğin yükseklik ve taban çapı değerlerinin diğer örneklere göre belirgin olarak daha yüksek olduğu, bununla ilintili olarak yükseklik/taban çapı, hacim verimi, özgül hacim değerlerinin daha iyi olduğu gözlenmiştir. Özellikle gözenek değeri ve kısmen pişme kaybı bakımından iki kez tavlı veya 48 saat süre ile tavlı olan örneklerin yekdiğerlerine (tavsız ve 24 saat süre ile bir kez tavlı) göre daha üstün oldukları saptanmıştır.

Ekmek örneklerinin renk özelliklerine ait verilerin incelenmesi ile (Çizelge 5), her iki çeşide ait tavlı buğday örneklerinden yapılan ekmeklerin kontrol örneğine göre daha açık oldukları saptanmıştır. Tav muamelelerinin $L^{*}$ değeri bakımından kendi aralarında bir farklılık olmadığ saptanmıştır. Adana-99 çeşidine ait ekmeklerin a* değerleri arasında istatiksel bir fark oluşmamıştır ( $\mathrm{p}>0.05)$. Rus çeşidinde ise kontrol örneğinin kırmızılık değerinin tavlı örneklere göre daha yüksek olduğu gözlenmiştir. Sarılık değerleri bakımından her iki buğday çeşidinde de kontrol örneklerinin daha az sarımtırak renge sahip oldukları, tav muamelesi ile ekmeklerin sarılık değerlerinin yükseldiği belirlenmiştir. Örneklerin Hue değerleri $L^{*}$ ve $b^{*}$ değerleri ile aynı yönde değişim göstermiş ve kontrol örneği bir grubu, tavlı örnekler ise diğer bir grubu oluşturmuştur. Chroma değerleri bakımından muameleler arasında bir farklılık ortaya çıkmamıştır. Tekstürel özelliklere ait verilerin incelenmesiyle (Çizelge 5), Adana-99 çeşidinde 24 saat süre ile bir kez tavlı olan, Rus çeşidinde ise 48 saat süre ile iki kez tavlı olan numunelere ait ekmeğin en sıkı özelliğe sahip olduklari belirlenmiştir. Her iki çeşitte de kontrol örneğinin sıkılığının en düşük değere sahip olduğu tespit edilmiştir. Burada elde edilen veriler Çizelge 4'de sunulan diğer ekmek özellikleri ile uyumlu bulunmuştur. Ekmek örneklerinin yaylana bilirlik değerleri arasında bir farklılık oluşmadığı gözlenmiştir.

Çizelge 5. Farklı Tavlama Muameleleri ile Öğ̈̈tülen Buğdayların Unlarından Üretilen Ekmeklerin Renk ve Tekstürel Özellikleri ${ }^{(1)}$

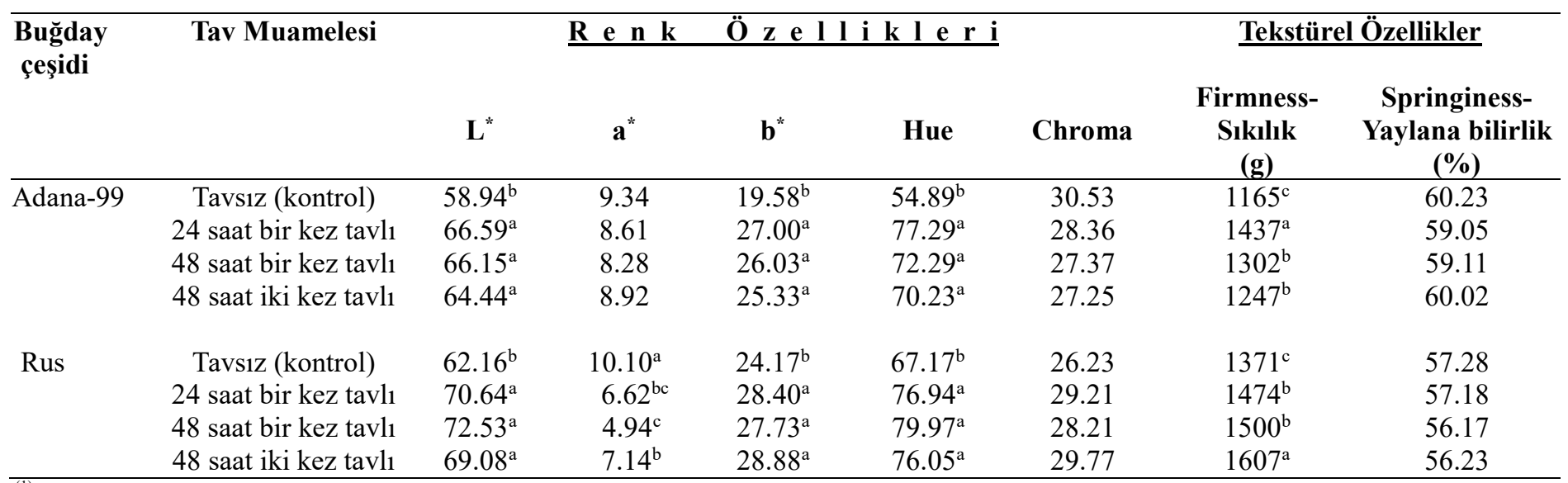

(1) Çizelgede aynı buğday örneği için aynı sütunda farklı harfle gösterilen değerler arasındaki farklar 0.05 güven sınırına göre önemlidir.

Konuyla ilgili yapılan çalışmaların irdelenmesiyle; tavlanmış buğdaylardan üretilen unlardan yapılan ekmeklerin hacim, gözenek yapısı ve tekstürel özelliklerinin aynı buğdayların tavlanmadan öğütülmesiyle elde edilen unlardan yapılan ekmeklere göre daha üstün kalitatif niteliklere sahip olduğu kanısına varılmıştır (Bayrakçı, 2008; Warechowska ve ark., 2016). Özellikle ısıl işlem içeren tavlama metotlarının zayıf özlü buğdayların ekmeklik niteliklerini geliştirdiği belirtilmiştir (Tekeli, 1964).

\section{Sonuç}

$\mathrm{Bu}$ çalı̧̧mada iki farklı ekmeklik buğdaya iki kez uygulanan tavlama işleminin buğdayın ekmeklik özellikleri üzerine etkileri araştırılmıştır. Bu anlamda 24 ve 48 saat süre ile iki farklı tav süresi ve 1 ya da 2 kez tavlama ile 2 farklı tavlama uygulaması yapılmasının mamul ürün (ekmek) üzerindeki etkileri araştırılmıştır. Çalışmadan elde edilen bulgular ve öneriler şu şekilde özetlenebilir: İncelenen ekmek nitelikleri bakımından, farklı tav muameleleri arasında çok sınırlı ölçüde bir farklılık oluştuğu, belirgin bir değişimin ortaya çıkmadığı (p>0.05) saptanmıştır. Ekmek yapma denemelerinde muameleler arasında tek düze bir uygulama olması bakımından örneklerin farinograf su absorbsiyon değerleri dikkate alınarak un örneklerine su verilmiştir. Ancak bu durumun hamurların sıkı bir yapıya sahip olmasına yol açtığı, hamur elastikiyetinin istenilen ölçüde olmadığı gözlenmiştir. Bundan sonra konu üzerinde yapılabilecek olası çalışmalarda ekmek hamuru formülünde yer alan bileşenlerin miktarına ve üretim işlem basamaklarında uygulanacak normlara ön denemeler ile karar verilmesinin daha uygun olacağ düşünülmektedir. Ayrıca ekmek üretim denemelerinin tavsız ve tav muameleleri neticesinde öğütülen buğdaylardan elde edilen unların 2-3 gün dinlenmesini takiben yapılmasının daha sağlıklı olacağı düşünülmektedir. Bulgular, tavlama prosesinde buğdaya verilen su miktarının kademeli olarak iki defada verilmesinin un niteliklerini geliştirme noktasında yarar sağladığına dair ipuçları içermektedir. Ancak bu konuda yapılacak olan daha başka çalışmalara ihtiyaç olduğu açıktır. Bundan sonra yapılacak olan çalışmalarda buğdaya yapılacak iki kez tavlama işleminin kinetiğinin incelenmesi ve ürün özellikleri üzerine etkisi daha geniş bir biçimde incelenebilir. Söz konusu çalışmada laboratuvar olanaklarının sınırlı olmasından dolayı araştırma sadece iki farklı buğday çeşidi üzerinde yürütülmüş ve yine olanakların sınırlı olmasından dolayı tekerrür sayısı kısıtlı tutulmuştur. Bu ve buna benzer çalışmaların daha çok buğday çeşidi üzerinde ve en az 3 tekrarlı olarak gerçekleştirilmesi durumunda daha sağlıklı analitik bulgulara erişilebileceği öngörülmektedir. Çalışma, soğuk tavlama metodu uygulanarak gerçekleştirilmiştir. İleriki çalışmalarda iki kez tavlamanın buğday, un, hamur ve ekmek kalitesine etkisi 1lık ve/ya da sıcak tavlama metotları ile araştırılabilir. 


\section{Bilgi Notu}

$\mathrm{Bu}$ çalı̧sma yüksek lisans tezinden üretilmiş olup, Osmaniye Korkut Ata Üniversitesi Bilimsel Araştırmalar Projeleri Birimi tarafından OKÜBAP-2017-PT3-033 proje numarası ile desteklenmiştir.

\section{Kaynakça}

AACCI, (2010). International Approved Methods of the American Association of Cereal Chemists (11th edition), Method 26-95.01; Method 39-11.01; Method 39-25.01; Method 74-09.01. St. Paul, MN: The Association.

Altan, A. (1986). Tahıl İşleme Teknolojisi. Adana: Çukurova Üniversitesi Ziraat Fakültesi Yayınları.

Atlı, A., Köksel, H. \& Dağ, A. (1988). Süne zararının ekmeklik buğday kalitesine etkisi ve belirlenmesi. I. Uluslararası Süne Sempozyumu, 13-17 Haziran 1988, Tekirdağ, s:1-19.

Bayrakçı, H. (2008). Buğdayın Tavlanmasında Mikrodalga Uygulamasının Öğ̈̈tme ve Ekmekçilik Kalitesine Etkisi Üzerine Bir Araştırma. Selçuk Üniversitesi Fen Bilimleri Enstitüsü, Konya.

Butcher, J. \& Stenvert, N.L. (1973). Conditioning studies on Australian wheats. III. The role of the rate of water penetration into the wheat grain. Journal of the Science of Food and Agriculture, 24, 1077-1084.

Diraman, H. (2010). Effect of microwaves on technological and rheological properties of suni-bug (Eurygaster spp) damaged and undamaged wheat flour. Food Science and Technology Research, 16(4), 313-318.

Diraman, H., Boyacıoğlu, M.H., Boyacıoğlu, D. \& Khan, K. (2013). Süne (Eurygaster spp) hasarlı buğdayların bazı protein fraksiyonları ve farinogram değerleri üzerine buharla tavlamanın etkileri. Glda Dergisi, 38(6), 359-365.

Dizlek, H. (2010). Süne Zararına Ŭgramış Ekmeklik Buğdayların Bazı Niteliklerinin İncelenmesi ve İyileştirilmesi Olanakları Üzerine Bir Araştırma. Çukurova Üniversitesi Fen Bilimleri Enstitüsü, Adana.

Dizlek, H. \& Gül, H. (2007). Süne zararlı buğday unlarının ekmeklik kalitesinin iyileştirilmesi. Uludağ Üniversitesi Ziraat Fakültesi Dergisi, 21(1), 51-58.

Dizlek, H. \& Gül, H. (2009). Required criteria for the definition of bread attributes I. Miller, 16, 56-65.

Dizlek, H. \& İslamoğlu, M. (2010). Buğday kitlesindeki süne emgi oranının belirlenmesinde ülkemizde kullanılan yöntemlerin karşılaştırılması. Uludağ Üniversitesi Ziraat Fakültesi Dergisi, 24(1), 81-90.

Dizlek, H. \& Özer, M.S. (2017). The effects of sunn pest (Eurygaster integriceps) damage ratios on bread making quality of wheat with and without additives. Quality Assurance and Safety of Crops and Foods, 9(1), 79-91.

Elgün, A. \& Ertugay, Z. (1997). Tahıl İşleme Teknolojisi. Erzurum: Atatürk Üniversitesi Ziraat Fakültesi Ofset Tesisleri.

Elgün, A., Ertugay, Z., Certel, M. \& Kotancılar, H.G. (2002). Tahıl ve Ürünlerinde Analitik Kalite Kontrolü ve Laboratuvar Uygulama Kılavuzu (Düzeltilmiş 3. baskı). Erzurum: Atatürk Üniversitesi Ziraat Fakültesi Ofset Tesisleri.

Elgün, A., Türker, S. \& Bilgiçli, N. (2005). Tahıl ve Ürünlerine Analitik Kalite Kontrolü. Konya: Konya Ticaret Borsası Yayını.

Finney, K.F. \& Bolte, L.C. (1985). Experimental micromilling: reduction of tempering time of wheat 18-24 hours to 30 minutes. Cereal Chemistry, 62(6), 454-458.

Francis, F.J. (1998). Colour Analysis: Food Analysis, Ed.: Nielsen, S.S., Springer New York Dordrecht Heidelberg, London, pp: $321-$ 389.

Hoseney, R.C. (1986). Principles of Cereal Science and Technology. St. Paul, MN: American Association of Cereal Chemists.

Ibanoglu, S. (2001). Influence of tempering with ozonated water on the selected properties of wheat flour. Journal of Food Engineering, $48(4), 345-350$.

Keskinoğlu, R., Elgün, A. \& Türker, S. (2001). Bir un değirmeninde uygulanan farklı 1lık tavlama işlemlerinin öğütme kalitesine etkisi. Glda Dergisi, 26(6), 419-427.

Keskinoğlu, R., Elgün, A. \& Türker, S. (2002). Bir un değirmeninde uygulanan farklı 1lık tavlama işlemlerinin öğütme kalitesine etkisi. II. Topyekün öğütme kalitesi kontrolünde kümülatif kül kurvesinin kullanılması. Gıda Dergisi, 27(2), 137-142.

Kweon, M., Martin, R. \& Souza, E. (2009). Effect of tempering conditions on milling performance and flour functionality. Cereal Chemistry, 86(1), 12-17.

MacRitchie, F. (2010). Concepts in Cereal Chemistry. Boca Raton: CRC Press.

Moss, R. (1977). The influence of endosperm structure, protein content and grain moisture on the rate of water penetration into wheat during conditioning. International Journal of Food Science and Technology, 12, 275-283.

Pyler, E.J. (1988). Baking Science and Technology. Manhattan, KS: Sosland Publishing Company.

SAS Institute (1982). SAS User's Guide to Statistical Analyses. Raleigh, NC: SAS Institute Inc.

Stenvert, N.L. \& Kingswood, K. (1976). An autoradiographic demonstration of the penetration of water into wheat during tempering. Cereal Chemistry, 53, 141-149.

Sünter, K. (2003). Buğdayın Farklı Sicaklık ve Sürelerde Tavlanmasının Unun Bazı Özellikleri Üzerine Etkisi. İstanbul Teknik Üniversitesi Fen Bilimleri Enstitüsü, İstanbul.

Tekeli, S.T. (1964). Hububat Teknolojisi. Ankara: Ankara Üniversitesi Ziraat Fakültesi Yayınları.

TSE (2003). Yemeklik Tuz, TS 933, Ankara.

TSE (2010). Ekmek, TS 5000, Ankara.

TSE (2012). Tahıl ve Tahıl Ürünleri - Numune Alma, TS EN ISO 24333, Ankara.

TSE (2015). Ekmek Mayası, TS 3522, Ankara.

TÜIK (Türkiye İstatistik Kurumu, 2019). Tahillar ve Diğer Bitkisel Ürünlerin Alan ve Üretim Miktarlart. http://www.tuik.gov.tr/PreTablo.do?alt id=1001 (Erişim tarihi: 20.01.2019).

Uluöz, M. (1965). Buğday, Un ve Analiz Metotları. İzmir: Ege Üniversitesi Ziraat Fakültesi Yayınları. 
Warechowska, M., Markowska, A., Warechowski, J., Mis, A. \& Nawrocka, A. (2016). Effect of tempering moisture of wheat on grinding energy, middlings and flour size distribution, and gluten and dough mixing properties. Journal of Cereal Science, 69, 306-312.

Yoo, J., Lamsal, B.P., Haque, E. \& Faubion, J.M. (2009). Effect of enzymatic tempering of wheat kernels on milling and baking performance. Cereal Chemistry, 86(2), 122-126.

ZMO (Ziraat Mühendisleri Odası, 2019). Buğday Raporu $\quad$ - 2018. http://www.zmo.org.tr/genel/bizden_detay.php?kod=30125\&tipi=17\&sube=0 (Erişim tarihi: 25.02.2019). 